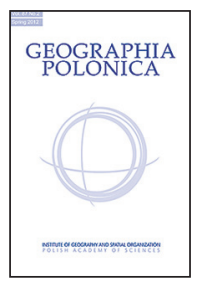 \\ INSTITUTE OF GEOGRAPHY AND SPATIAL ORGANIZATION \\ POLISH ACADEMY OF SCIENCES \\ www.igipz.pan.pl \\ www.geographiapolonica.pl
}

\title{
A MAP OF THE LANDSCAPE DIVERSITY OF POLAND
}

\section{Przemysław Śleszyński, Jerzy Solon}

Polish Academy of Sciences

Institute of Geography and Spatial Organization

Twarda 51/55, 00-818 Warsaw: Poland

e-mails: psleszyn@twarda.pan.pl・j.solon@twarda.pan.pl

\begin{abstract}
Presented here is a map of Poland drawn up to show differences in values obtained for the Shannon Diversity Index, as calculated using Corine Land Cover data for the 2012 situation regarding the country's landscape. The level of detail is that of the Polish commune (gmina - unit of local-government administration), so the analysis may prove to be of practical value. The same method gained previous use in depicting issues relevant to Poland's 2011 National Spatial Development Concept 2030.
\end{abstract}

\section{Key words}

landscape diversity - landscape typology - land use - Corine Land Cover - Shannon Diversity Index - anthropogenic landscape transformation

\section{Introduction}

Researchers from different geographical and ecological disciplines have long taken an interest in the spatial distribution of ecosystems and forms of land use, in association with diversity and heterogeneity analyses (Richling \& Solon 2011). The interest was further enhanced in the wake of the Rio UNCED or 'Earth Summit' of 1992, at which the Convention on Biological Diversity was open for signature. The CBD is a legal instrument stressing the particular environmental role of biodiversity at the intraspecific and species levels, but also at levels beyond that of the ecosystem. Where the latter are concerned, methods of research into environmental diversity have tended to develop in partial isolation, within different disciplines and sub-disciplines of the natural and earth sciences. For example, morphometric analyses of relief are based around indices of the length-breadth relationship, as well as depths of landforms (Steinhaus 1947; Najwer \& Zwoliński 2014), while 
interest is also taken in standard deviations associated with relative heights or elevations (Śleszyński 2014). In Poland, a detailed study was concerned with the shape of natural units (Pietrzak 1989), with a series of indices of circularity, dismemberment and so on deployed. The issue of the influence of vegetation's spatial structure on the diversity of the landscape as a whole was taken up by Solon (2002), while most contemporary approaches to the assessment of the landscape's spatial diversity are based around the concept of landscape pattern metrics (McGarigal \& Marks 1995). The latter approach is also becoming more and more popular in Poland (Kot \& Leśniak 2006; Kozieł 2008; Zwierzchowska et al. 2010; Niedźwiecki \& Kolecka 2011; Pukowiec-Kurda \& Sobala 2016), and is being used to generate different kinds of typologies and typological maps, especially on the basis of land-cover characteristics (Solon 2008; Niewiarowski \& Kot 2010; Łowicki \& Mizgajski 2013; Śleszyński 2014, 2015; Chmielewski et al. 2015); or else by reference to analysis of the linkage between land use and abiotic conditions (Solon 2007); or through assessment of the influence historical change has exerted on today's landscape structure (Solon 2006).

The last decade in particular has seen intensified interest in Poland's landscape diversity, undoubtedly in connection with the evergreater weight being attached to changes in the environment, including of an anthropogenic nature. Characterisations of the spatial structure of the landscape, e.g. as regards the size and shape of land-cover patches, also allow conclusions to be drawn regarding the history of given areas, and the spatial conflicts that may have arisen, e.g. in more-highlyurbanised parts of the suburbs (Solon 2005, 2009), or in and around protected areas (Bródka et al. 2012). It is particularly relevant for conclusion-drawing and recommendationmaking in spatial policy (and development policy more widely) that use should be made of analyses of landscape transformations based on universal, comparable indices or indicators (Solon 2008). And it is for this reason - among others - that the analysis presented here has been based around the Polish commune (gmina - unit of administration at local level), while the work also relates directly to a map of landscape diversity included in Poland's key binding document on spatial policy, the National Spatial Development Concept 2030 (MRD 2011; map no. 16).

\section{Methods and sources of data}

The analysis used Corine Land Cover ${ }^{1}$ (CLC) data detailing the situation in Poland as of 2012. Calculations were performed separately for each of the country's 2478 units of local-government administration at the socalled gmina (commune) level. The differentiation to the land cover in each commune was determined using several basic indices, i.e.:

- the number of CLC types present, expressed per $\mathrm{km}^{2}$ of area in the commune (Richness - R),

- the number of separate patches, expressed per $\mathrm{km}^{2}$ of area in the commune (Number of Patches - NoP),

- the diversity to the areal land cover according to CLC categories, as calculated using the Shannon Diversity Index (SDI), which combines evenness and typological diversity in line with the formula:

$$
H=-S p_{i} \log _{2} p_{i}
$$

where $p_{i}$ - is the share by area accounted for by category i (Shannon 1948; Shannon \& Weaver 1949),

- the density of patch edges per $\mathrm{km}^{2}$ of area in the commune (Edge Density - ED).

The indices referred to fall within the group of landscape composition metrics and are concerned with the differentiation and abundance of occurrence of different types of patch, regardless of their precise location in space (McGarigal \& Marks 1995).

1 The Corine Land Cover 2012 Project in Poland was implemented at the Institute of Geodesy and Cartography, with funding from the European Union. Results used in the work were obtained from the website of Poland's Chief Inspectorate for Environmental Protection (Główny Inspektorat Ochrony Środowiska) (clc.gios. gov.pl). 


\section{Results}

The spatial variability characterising the various indices analysed is of a clearly geographical nature. Both the number of types (CLC 2012 Richness) (Fig. 1) and the degree of landuse fragmentation (Fig. 2) are highest in the south of Poland, appearing to be progressively lower further to the north. A link between this and settlement structure is justified, with historical shaping of the population breakdown also relevant, as greater fragmentation of urban settlement and influence of agrarian structure proving characteristic for areas once falling within the Congress Kingdom of Poland and Galicia (i.e. the formerly Russian- and Austrian-partitioned parts of Poland).

The synthetic map of landscape diversity has been presented on an insert. The main map features two layers representing the Shannon Diversity and Edge Density Indices. This makes particularly plain a division of the Poland into a central and south-eastern part, and a north-western part. The south of Poland also emerges as different from the north in terms of the fragmentation of land-cover types, with this linking much more closely with habitat fragmentation. Also making itself felt is the influence of historical factors on the nature of the landscape mosaic, with this seen to be strongest in the formerly-Prussian or Austrian parts of Poland (even if the values for the landscape metrics in these two regions do in fact differ very markedly).

There are also clearly contemporary factors that influence diversity, like different means of organisation of rural settlement, and the defragmentation of the landscape as a result of urbanisation, transport and agriculture. In the case of farming it is a process of the ongoing division and sub-division of fields that has been involved, but also the status as only weakly mechanised, of low commercial viability and frequently existing solely to meet a farmer's own needs. The impact of urbanisation is in turn especially characteristic for the suburban zones of the largest agglomerations, including Warsaw, Poznań and the 'Tri-City' (Gdańsk-Sopot-Gdynia).
Also noteworthy is the way today's landcover diversity relates quite markedly to contemporary historico-cultural differentiation of the landscape in line with the division into regions arrived at by Plit (2016).

More detailed conclusions emerge when data on differentiation and diversity are expressed in relation to functional types of commune $^{2}$. The division here is into the 10 categories of: A - Functional Urban Areas (Miejskie Obszary Funkcjonalne, MOF) of the capitals of voivodeships (i.e. units of administration at provincial/regional level); B - external zones of MOFs; C - Functional Urban Areas of sub-regional centres; D - external zones of the latter; E - multifunctional urban centres; $\mathrm{F}$ - communes with a developed transport function; $G$ - communes with other developed non-agricultural functions (typically tourism or large-scale functions including in extractive industry); $\mathrm{H}$ - communes with an intensivelydeveloped agricultural function; I - communes with a moderately-developed agricultural function; J - communes only subject to extensive land-use and management (typically in forestry and/or nature conservation).

When data are set against the above classification it becomes clear that communes of the more-urbanised types (A-E, which is to say cities and/or their suburban zones) are characterised by values for all indices above the national average (Tab. 1). The converse situation

\footnotetext{
2 These are functional types of commune arrived at in the classification from Śleszyński and Komornicki (2016). They are based on a so-called deductiveinductive approach, devised conceptually to meet the needs of Mazowieckie Voivodeship (Śleszyński 2012). Where the identification of specific criteria is concerned, this is in turn a functional typology serving the process of monitoring in spatial planning (Komornicki \& Śleszyński 2008). The assignment of Poland's communes to categories is based on a classification procedure entailing four successive stages, i.e. the selection and determination of a hierarchy of categories in line with significance for spatial organisation, the choice of criteria appropriate to the given category (administrative or economic specifics, and so on), the arrangement of communes by reference to the detailed criteria, and an inductive process seeking internal differentiation and distinction (albeit via a search for similarities arising from the indices describing communes' developmental and morphological features).
} 


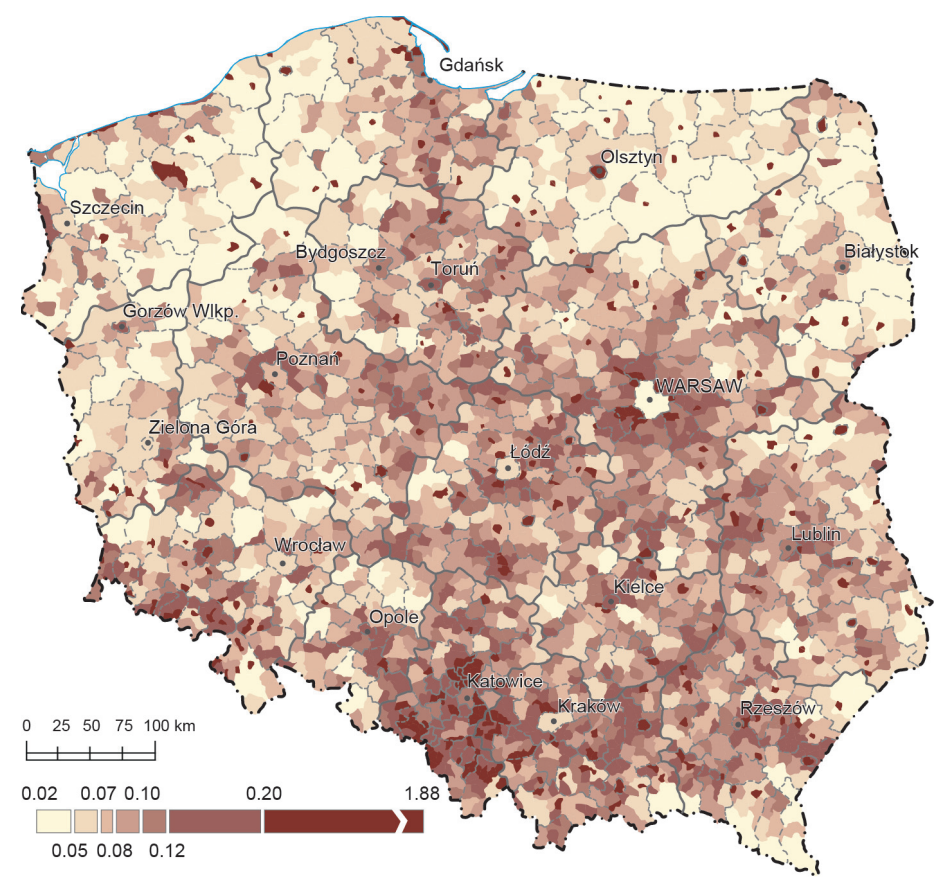

Figure 1. Richness per $\mathrm{km}^{2}$

Source: Corine Land Cover 2012.

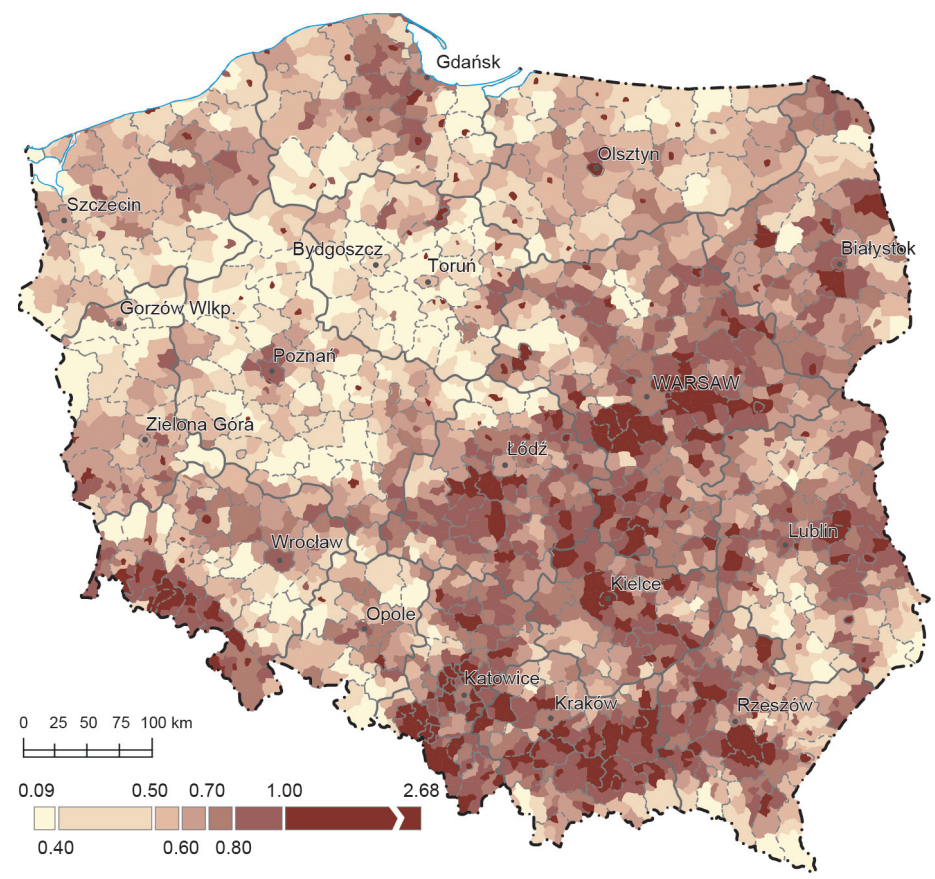

Figure 2. Number of Patches per $\mathrm{km}^{2}$

Source: Corine Land Cover 2012. 
Table 1. Differences between types of communes in values for indices calculated on the basis of CLC 2012

\begin{tabular}{|c|c|c|c|c|c|c|c|}
\hline \multirow{2}{*}{$\begin{array}{l}\text { Type of } \\
\text { commune } \\
(\text { gmina })^{\star}\end{array}$} & \multirow{2}{*}{$\begin{array}{l}\text { Number of } \\
\text { communes }\end{array}$} & \multirow{2}{*}{$\begin{array}{c}\text { Area } \\
\left({ }^{\prime} 000 \mathrm{~km}^{2}\right)\end{array}$} & \multirow{2}{*}{$\begin{array}{c}\text { Population } \\
\text { ('000) }\end{array}$} & \multicolumn{4}{|c|}{ Non-weighted means } \\
\hline & & & & R & NoP & SDI & ED \\
\hline A & 33 & 4.7 & 9,632 & 17.6 & 90.7 & 0.45 & 7.8 \\
\hline B & 266 & 27.9 & 4,432 & 18.7 & 86.2 & 0.38 & 7.3 \\
\hline C & 55 & 3.4 & 4,495 & 25.7 & 98.6 & 0.48 & 7.9 \\
\hline D & 201 & 21.4 & 2,352 & 15.8 & 83.1 & 0.38 & 7.4 \\
\hline$E$ & 147 & 10.6 & 3,927 & 36.7 & 97.3 & 0.48 & 7.3 \\
\hline $\mathrm{F}$ & 137 & 19.9 & 1,430 & 11.2 & 70.3 & 0.32 & 6.9 \\
\hline G & 222 & 33.6 & 1,809 & 12.6 & 69.7 & 0.35 & 6.9 \\
\hline $\mathrm{H}$ & 411 & 55.5 & 2,647 & 8.7 & 54.6 & 0.25 & 5.8 \\
\hline I & 748 & 93.3 & 5,624 & 10.9 & 71.3 & 0.33 & 7.1 \\
\hline J & 258 & 41.6 & 1,863 & 8.8 & 67.7 & 0.32 & 7.0 \\
\hline Total (Poland) & 2478 & 311.9 & 38,209 & 13.7 & 72.9 & 0.34 & 6.9 \\
\hline
\end{tabular}

* Abbreviations used in describing types of commune (after Śleszyński \& Komornicki 2016): A - Functional Urban Areas of voivodeship capitals; B - their external zones; C - Functional Urban Areas of sub-regional centres; D - their external zones; E - multifunctional urban centres; F - communes with a developed transport function; G - communes with other developed non-agricultural functions (tourism and large-scale functions, including mining); $\mathrm{H}$ - communes with an intensively-developed agricultural function; I - communes with a moderately-developed agricultural function; $\mathrm{J}$ - extensively developed communes (with forests or protected areas).

applies in the less-urbanized and peripheral areas (other than in the case of the ED index, whose values are close to the national average in weakly-urbanized communes).

While all of the indices analysed are intercorrelated, the strongest (Pearson Index) linear correlations are those pertaining between NoP and ED, as well as SDI and ED. Moredetailed analysis shows that these relationships tend to be non-linear in character, as for example in the case of SDI $\vee$ ED (see Figure on the insert).

Likewise, it is clear that, by analysing dependent relationships separately for distinguished functional types of commune, it is possible to note ways in which these localauthority areas assigned to different groups differ markedly from one another in their spatial organisation (Tab. 2).

Data in the Table show that, in the cases of communes of types $A$ and $C$ (in the cores of the Functional Urban Areas of voivodeship capitals or sub-regional centres), the relationship between SDI and ED is better described by a logarithmic model. This attests to clear differences from the remaining types, which are better-described using a logistic model. At the same time, the latter group is diverse internally, albeit characterised by more subtle differentiation. In respect of parameter $b$, type-F communes (those with developed transport infrastructure thus characterised by the clear presence of linear elements) differ significantly from types $G$ and J (i.e. communes with other developed functions outside agriculture (typically tourism or large-area functions) and communes only subject to extensive land-use and management (typically in forestry and/ or nature conservation). Beyond that, type-G communes also differ significantly from those of type I (with a moderately-developed agricultural function).

\section{Closing remarks}

The spatial diversity to be observed in today's Poland (as expressed in terms of Corine Land Cover categories) is conditioned by two groups of factors, of which the first are natural, including relief, and habitat-type most often 
Table 2. Modelled relationships between values of the SDI (as the dependent variable) and the ED index (independent variable) for different functional types of commune (local-level units of Poland's administration)

\begin{tabular}{|c|c|c|c|c|c|c|c|c|c|c|c|c|c|c|c|c|}
\hline \multirow{3}{*}{ Type } & \multicolumn{2}{|r|}{ Model } & \multirow{3}{*}{$\begin{array}{l}\text { Std } \\
\text { err }\end{array}$} & \multirow{3}{*}{$R$} & \multicolumn{4}{|c|}{ Parameter $a$} & \multicolumn{4}{|c|}{ Parameter $b$} & \multicolumn{4}{|c|}{ Parameter $c$} \\
\hline & \multirow{2}{*}{ name } & \multirow{2}{*}{ formula } & & & \multirow{2}{*}{ value } & \multirow{2}{*}{$\begin{array}{l}\text { std } \\
\text { err }\end{array}$} & \multicolumn{2}{|c|}{ range $(95 \%)$} & \multirow{2}{*}{ value } & \multirow{2}{*}{$\begin{array}{l}\text { std } \\
\text { err }\end{array}$} & \multicolumn{2}{|c|}{ range $(95 \%)$} & \multirow{2}{*}{ value } & \multirow{2}{*}{$\begin{array}{l}\text { std } \\
\text { err }\end{array}$} & \multicolumn{2}{|c|}{ range (95\%) } \\
\hline & & & & & & & $\min$ & $\max$ & & & $\min$ & $\max$ & & & $\min$ & $\max$ \\
\hline A & $\begin{array}{l}\text { Natural } \\
\text { Logarithm }\end{array}$ & $y=a+b^{\star} \ln (x)$ & 0.336 & 0.106 & 2.331 & 1.074 & 0.142 & 4.521 & 0.310 & 0.524 & -0.759 & 1.379 & & & & \\
\hline B & $\begin{array}{l}\text { Logistic } \\
\text { Power }\end{array}$ & $y=a /\left(1+(x / b)^{\star \star} c\right)$ & 0.356 & 0.691 & 2.945 & 0.158 & 2.634 & 3.256 & 3.575 & 0.199 & 3.183 & 3.968 & -2.150 & 0.358 & -2.854 & -1.445 \\
\hline C & $\begin{array}{l}\text { Natural } \\
\text { Logarithm }\end{array}$ & $y=a+b^{\star} \ln (x)$ & 0.299 & 0.357 & 1.562 & 0.421 & 0.718 & 2.406 & 0.571 & 0.205 & 0.159 & 0.982 & & & & \\
\hline D & $\begin{array}{l}\text { Logistic } \\
\text { Power }\end{array}$ & $y=a /\left(1+(x / b)^{\star \star} c\right)$ & 0.285 & 0.745 & 2.725 & 0.080 & 2.567 & 2.883 & 3.482 & 0.127 & 3.232 & 3.733 & -2.889 & 0.416 & -3.709 & -2.069 \\
\hline E & $\begin{array}{l}\text { Logistic } \\
\text { Power }\end{array}$ & $y=a /\left(1+(x / b)^{\star \star} c\right)$ & 0.361 & 0.616 & 3.327 & 0.671 & 2.002 & 4.653 & 4.145 & 0.933 & 2.301 & 5.990 & -1.630 & 0.695 & -3.004 & -0.257 \\
\hline $\mathrm{F}$ & $\begin{array}{l}\text { Logistic } \\
\text { Power }\end{array}$ & $y=a /\left(1+(x / b)^{\star \star} c\right)$ & 0.285 & 0.848 & 3.061 & 0.230 & 2.607 & 3.516 & 4.322 & 0.320 & 3.689 & 4.954 & -2.179 & 0.361 & -2.893 & -1.465 \\
\hline G & $\begin{array}{l}\text { Logistic } \\
\text { Power }\end{array}$ & $y=a /\left(1+(x / b)^{\star \star} c\right)$ & 0.283 & 0.619 & 2.780 & 0.141 & 2.502 & 3.058 & 2.938 & 0.183 & 2.577 & 3.299 & -2.144 & 0.511 & -3.150 & -1.138 \\
\hline $\mathrm{H}$ & $\begin{array}{l}\text { Logistic } \\
\text { Power }\end{array}$ & $y=a /\left(1+(x / b)^{* \star} c\right)$ & 0.299 & 0.807 & 2.682 & 0.164 & 2.360 & 3.004 & 3.816 & 0.259 & 3.306 & 4.325 & -1.920 & 0.230 & -2.373 & -1.468 \\
\hline । & $\begin{array}{l}\text { Logistic } \\
\text { Power }\end{array}$ & $y=a /\left(1+(x / b)^{\star \star} c\right)$ & 0.319 & 0.668 & 2.903 & 0.137 & 2.634 & 3.173 & 3.830 & 0.164 & 3.508 & 4.151 & -1.966 & 0.252 & -2.460 & -1.471 \\
\hline J & $\begin{array}{l}\text { Logistic } \\
\text { Power }\end{array}$ & $y=a /\left(1+(x / b)^{\star \star} c\right)$ & 0.275 & 0.668 & 2.669 & 0.098 & 2.475 & 2.863 & 3.269 & 0.152 & 2.969 & 3.568 & -2.529 & 0.452 & -3.419 & -1.640 \\
\hline all & $\begin{array}{l}\text { Logistic } \\
\text { Power }\end{array}$ & $y=a /\left(1+(x / b)^{\star \star} c\right)$ & 0.341 & 0.733 & 2.872 & 0.053 & 2.768 & 2.976 & 3.781 & 0.065 & 3.654 & 3.908 & -2.244 & 0.118 & -2.476 & -2.011 \\
\hline
\end{tabular}


expressed in terms of potential vegetation (cf. Solon 2007, 2008a). This primary conditioning is overlain by the impacts of numerous anthropogenic factors.

Presented analysis reveals that landscape is differentiated in markedly different ways in some regions of Poland as opposed to others, not least thanks to many different historical and contemporary processes. This leaves it worthwhile to ask about the future development of this already-visible differentiation and diversity. Two groups of factors would seem potentially able to play a more major role here, i.e. those whose anticipated impacts are typological (relating to the wealth of landscape types) and those with morphological impacts (relating to the dismemberment of the landscape into identifiable patches of differing sizes, as well as the development of their boundaries).

The above relate (on the one hand) to the expansion of settlement into areas that have been typically rural hitherto, the processes being suburbanisation and ongoing sprawl and dispersal of buildings (all the more intense given a lack of public control over these processes reflecting Poland's crisis in planning and spatial management). Clearly, these

\section{References}

Andrzejewski R., Weigle A. (eds.), 1993. Polskie studium różnorodności biologicznej. Warszawa: Narodowa Fundacja Ochrony Środowiska.

AndRzejewski R., Weigle A. (eds.), 2003. Różnorodność biologiczna Polski: drugi polski raport - 10 lat po Rio. Warszawa: Narodowa Fundacja Ochrony Środowiska.

BródKa S., Macias A., Stanek B., 2012. Przestrzenne aspekty zmian krajobrazowych na terenach chronionych na przykładzie Wielkopolskiego Parku Narodowego. Problemy Ekologii Krajobrazu, vol. 33, pp. 125-134.

KomORNICKI T., ŚLESZYŃSKI P., 2008. Struktura funkcjonalna gmin a postępy $w$ pracach planistycznych (2004-2006). Studia Regionalne i Lokalne, vol. 33, no. 3, pp. 53-75. processes will be most active and tangible in the vicinities of large or medium-sized cities, as well as most areas managed in the interests of tourism.

On the other hand, a process of quite the reverse nature in economic terms (encouraging a reduction in landscape diversity) will also be in action, namely severe depopulation affecting many peripheral regions and allowing for vegetational succession and the disappearance of edges of a markedly anthropogenic nature. The latter process can also enhance diversity in some cases, particularly in areas previously subordinated rather fully to the needs of agriculture.

The key processes in question obviously deserve - and offer opportunities for - cooperation between physical and socioeconomic geography, especially given far-reaching forecast changes in Poland's demographic and settlement structure, as well as the use made of its land.

Editors' note:

Unless otherwise stated, the sources of tables and figures are the authors', on the basis of their own research.

KorYCKA-SKORUPA J., 2007. Osanna Triangle as a form of presentation and legend of thematic maps. Polski Przegląd Kartograficzny, vol. 39, no. 4, pp. 340-353.

Kot R., LEŚNIAK K., 2006. Ocena georóżnorodności za pomoca miar krajobrazowych - podstawowe trudności metodyczne. Przegląd Geograficzny vol. 78, no. 1, pp. 25-45.

KozlEt M., 2008. Zastosowanie modelu geokompleksu do oceny zmian struktury krajobrazu w dolinie Wieprza. Problemy Ekologii Krajobrazu, vol. 21, pp. 273-286.

ŁowICKI D., MızGAuskı A., 2013. Typology of physical-geographical regions in Poland in line with land-cover structure and its changes in the years 1990-2006. Geographia Polonica, vol. 86, no. 3, pp. 255-266. 
McGarigal K., Marks B., 1995. FRAGSTATS: Spatial pattern analysis program for quantifying landscape structure. General Technical Report PNW-GTR-351, Portland (OR): USDA Forest Service, Pacific Northwest Research Station.

MRD, 2011. National Spatial Development Concept 2011. Warsaw: Minstry of Regional Development.

Najwer A., Zwoliński Z., 2014. Semantyka i metodyka oceny georóżnorodności: przeglad i propozycja badawcza. Landform Analysis, vol. 26, pp. 115-127.

NiedźWIECKI J., KoleCKA N., 2012. Ukształtowanie powierzchni terenu a wartości metryk krajobrazowych w górach wysokich na przykładzie Tatr. Prace Geograficzne, 128, Kraków: Uniwersytet Jagielloński, pp. 81-98.

Nienartowicz A., Kunz M., Domin D., 2001. Porównanie struktury krajobrazu na obszarach intensywnej i ekologicznie zrównoważonej gospodarki leśnej [in:] A. Nienartowicz, M. Kunz (eds.), GIS i teledetekcja w badaniach struktury i funkcjonowania krajobrazu, Toruń: Uniwersytet Mikołaja Kopernika, Wydział Biologii i Nauk o Ziemi, pp. 165-179.

NieWIAROWSKI W., Kot R., 2010. Delimitacja i charakterystyka gatunków i odmian krajobrazu naturalnego Pojezierza Chełmińsko-Dobrzyńskiego, Równiny Urszulewskiej oraz przyległych dolin Wisty i Drwęcy. Przegląd Geograficzny, vol. 82, no. 2, pp. 335-364.

NSDC, 2011. National Spatial Development Concept 2030. Warsaw: Ministry of Regional Development.

Pietrzak M., 1989. Problemy i metody badania struktury geokompleksu. Poznań: Uniwersytet Adama Mickiewicza.

PLIT J., 2016. Krajobrazy kulturowe Polski i ich przemiany. Prace Geograficzne, 253, Warszawa: Instytut Geografii i Przestrzennego Zagospodarowania PAN.

Pukowiec-Kurda K., Sobala M., 2016. Nowa metoda oceny stopnia antropogenicznego przekształcenia krajobrazu na podstawie metryk krajobrazowych. Prace Komisji Krajobrazu Kulturowego, vol. 31, pp. 71-84.

Richling A., Solon J., 2011. Ekologia krajobrazu. Warszawa: Wydawnictwo Naukowe PWN.
RYKOWSKI K., 1995. Ochrona różnorodności biologicznej w lasach [in:] R. Andrzejewski, R.J. Wiśniewski (eds.), Problemy różnorodności biologicznej, Dziekanów Leśny: Oficyna Wydawnicza Instytutu Ekologii PAN.

ShannON C.E., 1948. A mathematical theory of communication. The Bell System Technical Journal, vol. 27, pp. 379-423.

ShanNON C.E., WeAVer W., 1949. The mathematical theory of communication. Urbana: University of Illinois Press.

ŚLESZYŃSKI P., 2012. Klasyfikacja gmin województwa mazowieckiego. Przegląd Geograficzny, vol. 86, no. 4, pp. 559-576.

ŚLESZYŃSKI P., 2013. A geomorphometric analysis of Poland based on the SRTM-3 data. Geographia Polonica, vol. 85, no. 4, pp. 45-59.

ŚLESZYŃSKI P., 2014. The diversity of terrain and land cover in Poland. Geographia Polonica, vol. 87, no. 3, pp. 481-485.

ŚLESZYŃSKI P., KOMORNICKI T., 2016. Klasyfikacja funkcjonalna gmin Polski na potrzeby monitoringu planowania przestrzennego. Przegląd Geograficzny, vol. 88, no. 4, pp. 469-488.

ŚLESZYŃSKI P., 2015. Mapa krajobrazu kulturowego Polski w koncepcji przestrzennego zagospodarowania kraju 2030. Prace Komisji Krajobrazu Kulturowego, vol. 27, pp. 45-61.

Solon J., 2002. Ocena różnorodności krajobrazu na podstawie analizy struktury przestrzennej roślinności. Prace Geograficzne, vol. 185, Warszawa: Instytut Geografii i Przestrzennego Zagospodarowania PAN.

Solon J., 2005. Landscape diversity [in:] M. GutryKorycka (ed.), Urban sprawl. Warsaw agglomeration case study, Warsaw: Warsaw University Press, pp. 265-296.

Solon J., 2006. Granice mozaiki krajobrazowej a granica kulturowa [in:] J. Plit J. (ed.), Granice w krajobrazach kulturowych, Prace Komisji Krajobrazu Kulturowego, vol. 5, pp. 64-71.

SOLON J., 2007. Wpływ środowiska na zróżnicowanie kierunków rozwoju obszarów wiejskich. Biuletyn KPZK PAN, vol. 234, pp. 103-117.

Solon J., 2008a. Typy krajobrazu kulturowego Polski. Problemy Ekologii Krajobrazu, vol. 20, pp. 109-115. 
Solon J., 2008b. Kierunki standaryzacji metod badań krajobrazu do celów praktycznych. Przegląd Geograficzny, vol. 80, no. 1, pp. 39-54.

Solon J., 2009. Spatial context of urbanization: Landscape pattern and changes between 1950 and 1990 in the Warsaw metropolitan area, Poland. Landscape Urban Planning, vol. 93, no. 3-4, pp. 250-261.
SteinHaUS H., 1945. O wskaźniku ukształcenia pionowego. Przegląd Geograficzny, vol. 21, no. 1-2, pp. 113-115.

ZWIeRZChOWSKa I., StęnIEWSKA M., ŁoWICKI D., 2010. Możliwości wykorzystania programu Fragstats $w$ badaniach środowiska przyrodniczego. Przegląd Geograficzny, vol. 82, no. 1, pp. 85-102. 




CORINE LAND COVER DIVERSITY

by Przemysław Śleszyński \& Jerzy Solon

Scale 1.3000,000

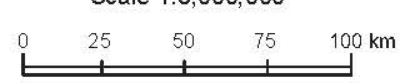

Shannon Diversity Index (SDI) in communes $\lcm{0.24}$

CLC border density in communes

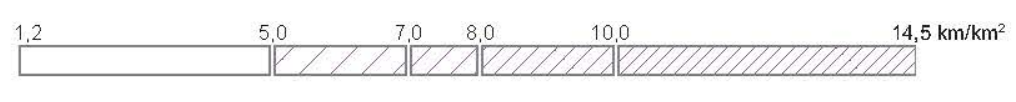

Borders of contemporary historical-cultural landscapes (after Plit 2016) provinces $\longrightarrow$ districts

Categories of cities and towns

- voivodeship capitals subregional centers - poviat capitals

Relationship between CLC 2012 diversity (SDI)

and CLC 2012 edge density (ED) in line with the logistic power model

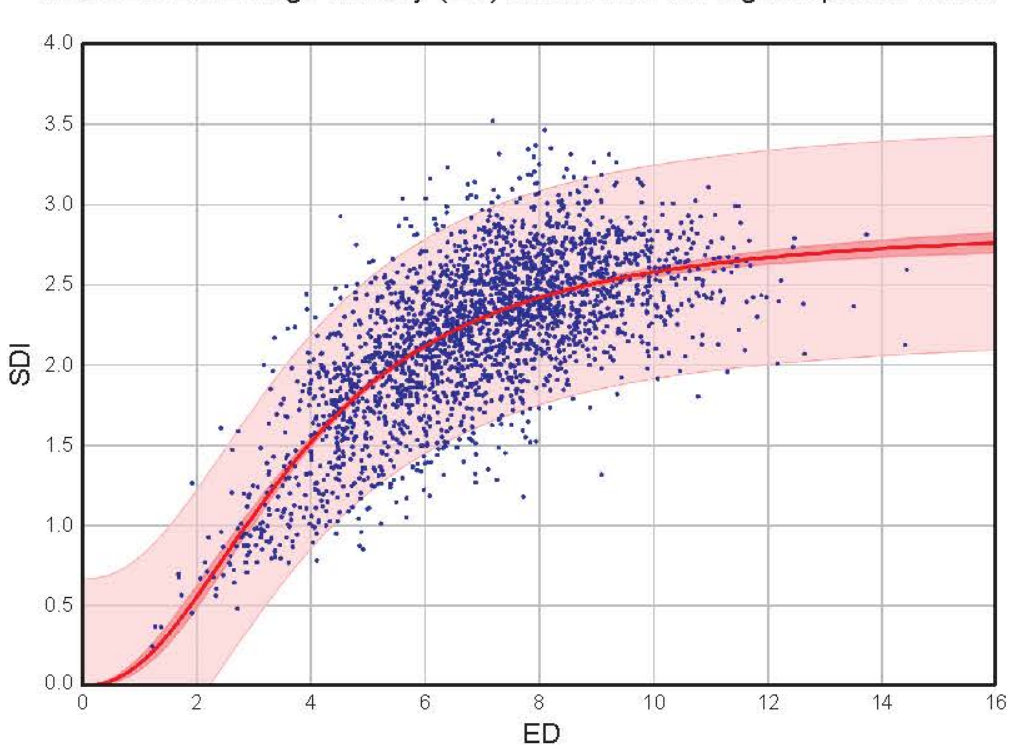

data model $\quad$ confidence band $\square$ prediction band

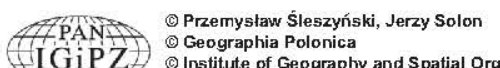

Polsh Acaderny of Sciences, Warsaw, 2017

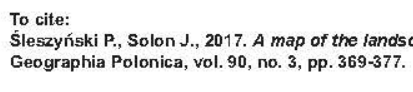

